\title{
Bullying and Cyberbullying: A Legal and Public Policy Perspective in Colombia
}

\author{
Milton Arrieta-López* and Laura Patricia Carrasquilla-Díaz \\ Department of Law and Political Science, Faculty of Law, Universidad de la Costa CUC, \\ Barranquilla, 080002, Colombia
}

\begin{abstract}
Children and adolescents have evolved in the cultural contexts of the digital age as a result of the technological revolution, which has led to new forms of bullying. This research consists of analyzing bullying and cyberbullying in Colombia from a legal perspective. The methodology used is the legal analysis of law and policy documents on school matters in Colombia. It is concluded that restorative justice should be used in cases of bullying and cyberbullying, taking into account that it enables spaces for reconciliation and restoration of the infringed damage. It also involves victims, perpetrators, and the educational community in its process. In terms of public policies, considering the severe damage caused by cyberbullying, it is advisable to consider the school programs' implementation that informs potential victims about the precautions they should take to avoid the risks of virtual harassment.
\end{abstract}

Keywords: Cyberbullying, harassment, personal privacy, public education policies, virtual society

\section{INTRODUCTION}

In Colombia, the use of the Internet has become more widespread in recent years. However, this new space has not only

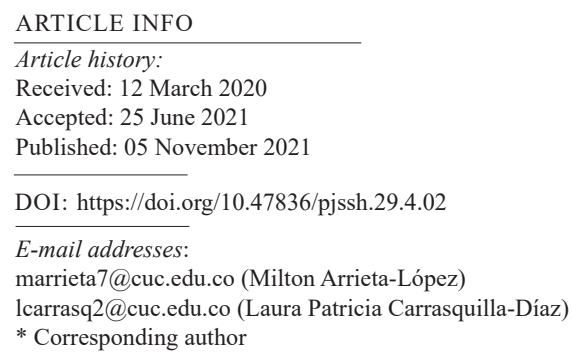

been useful to simplify life but has also spread real-world problems (BecharaLlanos, 2018). One of the most significant problems is cyberbullying. It mainly affects young people who are avid consumers of technology (Abuín-Vences et al., 2019).

This article will analyze the phenomenon of bullying and cyberbullying in Colombia from a legal perspective within policy documents on school matters. The qualitative research and the legal analysis of law and policy documents facilitated the inquiry, the 
recovery, the study, and the interpretation of secondary data. This data involves laws cases, legal textbooks, Colombian laws, jurisprudence, and doctrine to expand and build more knowledge.

\section{The Impact of Globalization on Virtual Environments}

Globalization is usually understood as a succession of events on a planetary scale tending to aggregate national economies into the world economy. This process is based on the conceptual archetypes of productive specialization and international trade. It is evident from the public economic policies of national states which emerged in the 1980s. These policies favored globalization through strategies to insert their economies into different regional and international economic spheres (Obstfeld, 2021). Because of this process, national States have adapted their domestic legal system. It is achieved by enacting favorable legislation for the free movement of capital, services, manufacturing, raw materials, and companies (Arrieta-López et al., 2019).

Nevertheless, this barely represents one side of the globalizing phenomena. Globalization also implies processes of permanent rupture of certain boundaries historically imposed on technology and cross-border's links between human beings (Arrieta-López, 2018). Globalization has enabled not only those mentioned above profound political and legal changes but also technological advances. It takes place, among other reasons, because technology constitutes the main instrument that drives globalization in its other dimensions (Kowalski et a1., 2014). Barreda et al. (2012) has pointed out the following concept on the relationship between globalization and international society:

Globalization is only partially a natural process of international society. It is also to the extent that human beings are sociable by nature and tend to communicate with other members of their kind - for reasons of survival, innate sense of solidarity, lack of self-sufficiency in the pursuit of their interests, etc.-by developing technologies that intensify the consequences of their innate sociability. (Barreda et al., 2012, p. 4)

It should be emphasized that globalization is not a natural process. In other words, it does not comprise events that result from the economy's immutable laws (Alfaro, 2020). Instead, globalization, to a large extent, is a social construction produced by global and individual human determinations (Arrieta-López, 2019).

Transportation, communications, and information technologies are affecting the lives of human beings up to the point of becoming one of the main current references of cultural globalization (Silva, 2008). Although communications and information technologies (ICTs) play a preponderant role in social development and national and global productions, their cross-curricular thematic in society implies a determining 
element for certain problems emerging in the contemporary world (Arrieta-López, 2020). Online platforms, for example, through their interactivity, link millions of people from almost every nation-state in the world (Abdel-Wahab, 2012). As a result, it has generated not only new communication paradigms but also severe new problems. One of these problems is cyberbullying.

\section{Bullying and the Emergence of Cyberbullying}

Bullying is usually described as premeditated and intentional psychological and physical abuse. It involves the permanent repetition of aggression and mockery of a minor by another or others. The responsible individual is usually similar in age, whose purpose leads to cruel subjugation and social exclusion of the bullied (Hinduja \& Patchin, 2010). Olweus (1998), professor of psychology at the University of Bergen, was the first to define bullying as "mistreatment by peer abuse." It involves acts of psychological or physical persecution by the bullying student or students against another student or students who are singled out as victims of repeated and vicious attacks.

Eyuboglu et al. (2021) and Roldán (2013) explain that any form of psychological abuse or extreme violence between students repeatedly over some time is continuous torture. In this situation, the aggressor subjugates, marginalizes, and despises the victim. It is all conducted in the face of the indifference, silence, and complicity of other colleagues. The abused victim remains emotionally in the hands of the aggressor, who generates severe consequences in a minor who has not yet forged his personality (Alcaine \& Sánchez, 2020).

Guinot (2013) specifies the type of violence contained in the bullying as follow:

According to the English term, what we are talking about is a kind of abuse that occurs in the classrooms. It is also said that this scenario can last from the beginning of elementary school and end with high school. (Guinot, 2013, p. 29)

ICTs have been used as a means for bullying. It affects the social life of the victims in the framework of social networks (Abbasi et al., 2018). Consequently, among the different forms of bullying, a new trend called cyberbullying has emerged. This type is defined as a succession of malicious and offensive behavior that manifests itself over long periods and uses electronic media to destroy and subjugate the victims affected by the harassment. (Chan et al., 2021).

According to the Constitutional Court (Ruling T-365, 2014), cyberbullying is based on the weapon sensation of transport, ICTs to intimidate, bully, harass and exclude an individual or group from another larger community. Therefore, it is essential to emphasize the seriousness of cyberbullying. Furthermore, according to Carvalho et al. (2021), González-Prada et al. (2015), and Li (2006), bullying among peers through new technologies can have severe consequences for the victim, which in extreme cases can lead to suicide. 


\section{METHOD}

This is a qualitative research with a legal analysis of law and policy documents on school topics. We recovered, studied and interpreted secondary data such as texts of doctrine, jurisprudence, laws and decrees of the Colombian legal system and public policies documents of the city of Bogotá. Three selection criteria were applied in the search for information: relevance and scope of the proposed objectives; completeness in the review of all available sources, and timeliness. This information allowed us to define the elements of analysis related to bullying and cyberbullying in Colombia from a legal research perspective.

\section{RESULTS AND DISCUSSION}

\section{Rights Affected}

In the Colombian legal system, a specific norm describes cyberbullying (Law 1620, 2013). However, there are other legal guarantees based on fundamental rights, in addition to certain specific rules that protect the victims of bullying and that are contained in the Code of Childhood and Adolescence (Law 1098, 2006).

Based on this, the Constitutional Court (Ruling T-713, 2010) has indicated that:

One of the problems that have increased with new technologies is school bullying. (...) Information technologies have had a negative impact on this type of behavior by increasing the harm caused by many of the attacks and harassment that a student may suffer. (...)
According to the National Police, when a person torments, threatens, harasses, humiliates, or annoys another person through the internet, mobile phones, games consoles, or other similar technical means, it is considered cyberbullying. (para.

72)

Colombia has incorporated first generation human rights into its domestic legislation, such as human dignity, good name, honor, and privacy. These fundamental norms become the first guarantees against cyberbullying. Consequently, the Constitutional Court (Ruling T-261, 1995) stated the following about the right to personal and family privacy:

It is derived from human dignity and the natural tendency of every person to have freedom, autonomy, and self-preservation and protect the private sphere of the individual and his or her family as the closest human nucleus. Both are in a position to demand a minimum particular and public consideration of their interiority. (...) These are not part of the public domain; therefore, they should not be the subject of information provided to third parties, intervention or analysis of outside human groups, or disclosures or publications. (para. 33)

The above jurisprudential development served as a basis for establishing the five principles that underpin the safeguarding 
of the right to privacy. According to the Constitutional Court (Ruling T-787, 2004), without it, "the corresponding intangibility of the guaranteeing content of the immunity of the individual from the necessary interference of others would be lost" (para. 128). It implies that these five principles must be legally manifested to make legitimate an intrusion or intrusion against a person's privacy.

Five principles support the protection of the right to privacy. The principle of freedom states that the personal data of an individual may only be recorded or disclosed with the free, prior, express, or tacit consent of the holder unless the legal system imposes an obligation to disclose such information to fulfill a constitutionally legitimate objective. (...) The principle of purpose states that it must be expressed in the requirement to submit the collection and disclosure of data for the realization of a constitutionally legitimate purpose which prevents forcing citizens to disclose intimate data about their personal life without support in the Constitutional Text that legitimizes the release of part of their interiority for the benefit of the community. The principle of necessity states that the personal information to be disclosed is strictly limited to that which is related to the purpose of the disclosure. Thus, the recording and disclosure of data that exceeds the constitutionally legitimate purpose are prohibited. In addition, the principle of truthfulness states that it is required that the personal data that may be disclosed correspond to real situations; therefore, the disclosure of false or erroneous data is prohibited. Finally, the principle of completeness states that the information to be disclosed must be provided in full. In this way, it prevents the recording and disclosure of partial, incomplete, or fractioned data. (Ruling T-787, 2004, para. 129)

The five principles set forth in Ruling T-787 of 2004 entirely lead to the protection of the right to privacy when cyberbullying occurs. It takes place because the bully has no legitimacy to violate the limits of the right to privacy, particularly if one takes into account that "social networks are a multiplying channel of the information that is published there, so that a person cannot use this media to disseminate personal information without causing this action to harm the fundamental right to privacy" (Piedrahita, 2011, p. 4).

It is worth mentioning the right recognized by the Colombian Political Constitution in Article 13, Constituent Assembly of Colombia (Political Constitution of Colombia, 1991), which can protect citizens from bullying. This article states that:

All individuals (...) will receive equal protection and treatment 
from the authorities and will enjoy the same rights, freedoms, and opportunities without any discrimination on account of gender, race, national or family origin, language, religion, political opinion, or philosophy (...). (Colombian Political Constitution, 1991, art.13)

Article 13 safeguards the rights of individuals taking into account that it establishes fundamental guarantees against cyberbullying. The Code of Childhood and Adolescence contained in Law 1098 of 2006 (Congress of the Republic of Colombia, 2006) is another instrument established in the Colombian legal system that is useful in the issue of bullying. These advocates, among other guarantees, the protection framework against bullying. It is based on the principles of comprehensive protection of children and adolescents and the best interests of children and adolescents, both positive in the instrument above (Law 1098, 2006, art. 8).

It must be added to these principles the protection of the personal integrity of children and adolescents for which the Code for Children and Adolescents states:

This Code states that child abuse is understood as any form of prejudice, punishment, humiliation, physical or psychological harm, neglect, omission or negligent treatment, mistreatment or exploitation, including abusive sexual acts and rape and, in general, any form of violence or aggression on the child or adolescent by their parents, legal representatives or any other person. (Law 1098, 2006, art. 18)

The article mentioned above refers to bullying in the understanding that it protects minors against any harm to their physical and psychological integrity (Piedrahita, 2011) by members of their school and community group. However, it was not until the enactment of Law 1620 of 2013 that the Colombian legal system described cyberbullying together with the conduct of bullying both concepts as follows:

Bullying has consequences on the
health, emotional well-being, and
school performance of students,
the learning environment, and on
school climate of the educational
establishment. Cyberbullying or
school cyberbullying should be
understood as a form of bullying
with the deliberate use of
information technologies (internet,
virtual social networks, mobile
telephony, and online video games)
to exercise psychological and
continuous mistreatment. (Law
1620,2013 , art. 2)

According to Law 1620 of 2013 , cyberbullying is not described as harassment but as a form of intimidation that continuously uses transportation, communications, and information technologies to exercise psychological mistreatment. As a consequence of the referred problem, the 
National System of School Coexistence and Training for Human Rights, Education for Sexuality and Prevention and Mitigation of School Violence was instituted among other functions in articles 7 and 8 of the law mentioned above to create "mechanisms for reporting and monitoring on the Internet, social networks and other information technologies to cases of cyberbullying" (Law 1620, 2013, art. 8.9). Likewise, the education secretariats were assigned the responsibility of promoting the "development of citizenship competencies, the exercise of Human, Sexual and Reproductive Rights," the promotion of "healthy lifestyles," and the prevention of "bullying and cyberbullying in Complementary School Days" (Law 1620, 2013, art. 16.6).

Even though since the second decade of the 21 st century, there is legislation in vigor against cyberbullying, there is a notorious lack of evidence-based anti-cyberbullying programs built on national, regional, and local research (Hernández et al., 2009). Law 1620 (2013) and Act 1965 (2013) are not entirely effective since there are no precise legal resources against cyberbullying regarding the penalization of punishable conducts that may involve the different forms of virtual bullying. In addition, there is a lack of special precautionary or preventive measures that can be requested before officials with jurisdictional power to stop the use of transportation, communications, and information technologies due to bullying manipulation in virtual media.

\section{The Public Policy of School Life in Colombia}

The events that occur during the "school stage" are important that children experience in educational establishments are essential for developing their personality and will mark their lives for many years after its culmination (Kowalski et al., 2013). The relationships that develop during the school stage constitute school coexistence. It does not mean the absence of conflicts, but rather that they are handled without violence. Then, coexistence refers to the quality of relationships conducive to consensus, mutual recognition, respect, dialogue, and the positive valuation of living while respecting and recognizing differences (Secretary of Education of Bogotá, 2019).

Being a guarantor of the fundamental right to education (Political Constitution, articles 44 and 67), the State must develop a public policy that determines the conditions under which it will be carried out. It also must indicate how to resolve the conflicts that arise and affect school coexistence. According to the definition adopted by Velásquez (2009), a public policy, is an inclusive process of decisions, actions, inactions, agreements, and instruments, developed by public authorities with the possible participation of individuals aimed to solve or prevent a situation defined as problematic. Therefore, it should include not only the identification of the situations that are considered conflictive but also the range of actions to be undertaken depending on the nature and seriousness of the situation as well as the entities that 
should be articulated for their correct management and subsequent follow-up.

Concerning the State's public policies, the Constitutional Court (Ruling C-351, 2013) has pointed out that any public policy aimed at guaranteeing a constitutional right should have a priority to guarantee the effective enjoyment of the right. Therefore, a review of the public policy of the State in relation to school coexistence should not be limited to an analysis of its content, but also of its application, taking into account that its existence is of no use if it is not applied or if its application leads to nonexistent mitigation of the problems it seeks to address.

The National System for School Coexistence and Training for the exercise of Human Rights, education for sexuality, and the prevention and mitigation of school violence (SNCE) were enforced by Law 1620 of 2013 (regulated by Decree 1965 of 2013), which is composed by two instrument: the Unified Information System for School Coexistence (SIUCE) and the Integral Attention Route (IAR). The NSSC aims to prevent and mitigate situations that affect school coexistence and the exercise of human, sexual and reproductive rights, including bullying and cyberbullying.

Among the pillars of these tools is the classification of situations that affect school coexistence and the exercise of human, sexual and reproductive rights into three types, as it is stated in Decree 1965 (2013):

Type I situations. Examples of this type are the conflicts handled inadequately and those sporadic situations that negatively affect the school climate and that in no case generate damage to the body or health. Type II Situations. Examples of this type are the situations of school aggression, bullying, and cyberbullying, which do not have the characteristics of the commission of a crime, and that comply with any of the following characteristics: a) That they occur repeatedly or systematically. b) That they cause damage to the body or health without generating any disability for any of the parties involved. Type III Situations. Examples of this type are the situations of school aggression that are part of alleged crimes against freedom, integrity, and sexual training, referred to in Title IV of Book 11 of Law 599 of 2000 , or when they constitute any other crime established in the Colombian criminal law in force. (art. 40).

According to the seriousness of the situation will be the different scenarios of the current educational institution. Therefore, the alluded tools of the NSSC are defined. On the one hand, the SIUCE is defined as a System for the Identification, Registration, and Follow-up of cases of harassment, school violence, and violation of sexual and reproductive rights that affect children and adolescents in educational establishments (Law 1620, 2013).

Therefore, it is a technical tool that is fed by case reports. Only information that guarantees the identification, registration, and follow-up of type II and types III situations should be reported to the SIUCE. In this sense, the SIUCE is considered 
a tool for improving public policy on school life. It creates strategies in favor of peaceful school relationships, conducts research on school harmony situations, and undertakes more effective actions to prevent violence in schools. Nevertheless, young people reported will have their information accessible to any educational entity, which implies that it may be grounds for nonadmission in any of these.

On the other hand, the Integral Attention Route -IAR- defines the institutions' processes and protocols to be followed in all cases where school coexistence is affected (Law 1620, 2013, art. 29). Therefore, it could be considered that the IAR is the travel route that indicates the stops to be made at each stage of the path of prevention, promotion, care, and monitoring of situations that affect school coexistence. Hence, these are precisely its four components.

Act 1965 of 2013 also established that educational institutions should create protocols to set the necessary procedures to timely assist the educational community in situations that affect school coexistence and the exercise of human, sexual and reproductive rights. Such protocols would establish different actions, depending on the type I, II, or III situations presented.

For type I situations, mediation with the persons involved is the first step to follow. Schools should ensure forms of dispute in an impartial, equitable, and fair manner. It must aim to seek reparation of damages caused, restoration of rights, and reconciliation. They are as follow:

1. Mediate pedagogically with the people involved.
2. Establish forms of solution in an impartial, equitable, and just manner, seeking reparation for the damage caused, the restoration of rights, and reconciliation.

3. Follow up on the case and the commitments.

Only in Type II and III situations, in cases of harm to body or health, should the parents or guardians of students be involved immediately without mediation being attempted first. In such cases, the school must guarantee immediate attention to the physical and mental health of those involved by referring them to competent entities. The procedure should be:

1. In cases of damage to the body or health, guarantee immediate attention to the physical and mental health of those involved through referral to the competent entities.

2. When measures to restore rights are required, refer the situation to the administrative authorities.

3. Adopt measures to protect those involved in the situation from possible actions against them.

4. Immediately inform the parents or guardians of all the students involved.

5. Generate spaces where the parties involved and the parents, or guardians of the students, can expose and specify what happened. It must be done while preserving, in any case, the right to privacy, confidentiality, and other rights.

6. Determine the restorative actions that seek the reparation of the 
damages caused, the restoration of rights and reconciliation, as well as the consequences applicable to those who have promoted, contributed, or participated in the reported situation.

7. The committee will carry out the analysis and the follow-up.

8. The school coexistence committee will record everything that happened. The decisions must be made in the minutes. All members and participants must signed them.

9. The president of the school coexistence committee will report the case's information to SIUCE.

In both type II and III situations, the school is obliged to generate spaces in which the parties involved and the parents or guardians of the students can expose and clarify what happened. It is done while preserving, in any case, the rights to privacy and confidentiality. At last, type (III) procedure should be as follow:

1. In cases of damage to the body or health, it must be guaranteed immediate attention to the physical and mental health of those involved through referral to competent entities.

2. Parents or guardians of all the students must be immediately informed. These actions will be recorded.

3. The president of the School Coexistence Committee will immediately bring the situation to the attention of the National Police in the most expeditious way.
4. The president of the school coexistence committee will inform the participants in the committee of the facts. However, the president will also keep confidential information that may violate the right to privacy and confidentiality of the parties involved as well as the report made before the competent authority.

5. The school coexistence committee will adopt the measures of the educational establishment aimed at protecting the victim who received the aggression and the people who have reported or are part of the situation presented within the scope of its powers. This performance will be recorded.

6. The president of the school coexistence committee will report the information of the case to SIUCE.

7. The cases subject to this protocol will be monitored by the school coexistence committee, the authority that assumes the knowledge and the municipal, and the district or departmental school coexistence committee that exercises jurisdiction over the educational establishment in which the situation took place.

In order to analyze the tools used by the public policy of school coexistence in Colombia, a case is presented. The events took place in 2014 while being already the SNCE in action. Sergio, a 17-year-old boy, was holding a romantic relationship 
with a classmate. Their parents, as well as the educational institution, were unaware of their relationship. It all started when a teacher confiscated the cell phone that contained a photo of a kiss between the two boys taken outside the school while wearing their uniforms. Both young people were called the next day to appear before a school psychologist because, as they were told, they had committed serious misconduct. The manual of coexistence of the college pointed out as a serious fault any manifestation of love obscene, vulgar, or grotesque in couple relationships inside and outside our institution, or wearing the same uniform.

The college decided to make parents of teenagers aware of the disciplinary process in progress and their sexual orientation. Following that meeting, while the parents of Sergio reacted by supporting their child, the parents of the other boy not only disagreed but also decided to engage in a criminal prosecution of Sergio for the charge of "sexual harassment" against their son. After this meeting, the school's directives were later classified in court as harassment from an institution to a student. They can be summarized at the following:

- Only the permanence of Sergio in the educational institution was conditioned to their directions. The other boy was never jeopardized.

- They demanded that Sergio had to obtain external psychological accompaniment. However, they did not ask the same for the other boy.

- Despite both young people kept a follow-up with the psychologist of the institution and accepted on multiple occasions to be holding a romantic relationship, the institution never presented this as evidence in the criminal investigation.

- The criminal investigation only aggravated the already difficult situation of Sergio with his peers. He was already a bullied boy, but now every school's decision gave his peers more reasons for the harassment to continue.

- As a result of one of the sessions with the school psychologist in which Sergio stated that his mother had to travel regularly to another city, the institution established a complaint of abandonment against the child's mother before the Institute of Family Welfare. They stated to the assigned social worker that his "sexual deviation" was due to the mother's absence.

A few days after the mother of Sergio finally decided to withdraw his son from college, he committed suicide. The director of the college was later interviewed by the media, pointing out the cause of the death of the minor, the abandonment of his mother, his sexual orientation, and his political ideas. The school position was later reaffirmed in a public statement sent to every parent's e-mail account.

The mother of Sergio decided to request the constitutional protection of her son's rights to equality and non-discrimination. She had previously (even when Sergio was alive) tried to reach the Educational Secretary 
authorities, but she never had an answer. She pointed out that the college adopted a systematic behavior of discrimination against the teenager, motivated primarily by his sexual orientation. The ruling of the Constitutional Court (Ruling T-478, 2015) regarding this case agreed that there was an evident difference in the way they treated Sergio and Horacio. It became the first time that it was accepted that bullying could occur not only between peers but also from a person or institution in a higher position.

This shift was important. The Constitutional Court also questioned the efficacy of the NSSC. In 2014, SIUCE had not been implemented by the Ministry of National Education, and, as for the IAR. However, the content of the protocols was clear; Act 1965 had not established a deadline for educational establishments to adopt them. Furthermore, it was clear that before advancing a pedagogical process between the parties for the events that occurred, the school preferred to initiate a disciplinary-sanctioning process without promoting a space for conciliation that included Horacio's parents. Despite this, the school ignored the value of dialogue and the collective construction of solutions in the academic environment. It was also noted that Educational Secretary authorities failed to fulfill their legal obligations.

For this reason, the court ordered the Ministry of National Education to implement the necessary actions for the creation of the National School Life System within a maximum period of six months as stated in Law 1620 of 2013 and Decree 1965 of 2015. It also set a deadline of one year to perform an extensive and comprehensive review of all school behavior guidelines ${ }^{1}$ in the country to determine that they are respectful of students' sexual orientation and gender identity. Thus, it was not until after this ruling that actions were taken to implement the mechanisms already provided for in the public policy on school coexistence, such as SIUCE and RAI. A systematic review of the school behavior guidelines was carried out.

After this, most schools had to revise their internal rules to transition from a disciplinary-sanctioning process policy to a pedagogic process in a conflict scenario. As shown in Sergio's case, it evolved in a rapid and almost uncontrolled manner. What started as a Type I situation, in which it was necessary to mediate pedagogically with the people involved, ended with a suicide. All this took place within three months, between June and August 2014. In order to comply with the court's orders, the Ministry of National Education had to create guidance for the educational institutions to make those changes.

The final result was the publication of guidance books (in some cases, these books were just one-page long infographics) with general orientations regarding the suggested content of the rules of coexistence and the procedures to follow when conflict occurs. These books also aimed to prepare educational institutions and teachers in

\footnotetext{
${ }^{1}$ The behavior guidelines is a document that is part of the Institutional Educational Project of a school in Colombia and contains the set of principles, rules, procedures and other aspects that regulate and make possible the coexistence of the members of an educational institution.
} 
general because it was evident that an incorrect assessment of the situation could imply that the competent entities may never handle a case if it is never reported by the person who first handles it. Sergio's case had shown that perhaps, the weakest part of the Colombian public policy on school coexistence is that its correct functioning depends on the people in the institutions.

There is no doubt that several educational institutions across the country have changed their rules of coexistence by making a shift in their policies. However, to the date this research was carried out, there was not a study made by the Ministry of Education or any other authority that intended to supervise and corroborate those changes were done. There is also a serious doubt regarding if the published guidance books were enough to comply with the court's orders. It is our opinion they were not. The other weak point is how the measures created by IAR had to be implemented. It is another issue that is currently unsupervised.

\section{CONCLUSION}

Bullying and cyberbullying constitute discrimination when unwanted conduct occurs and is linked to some suspected discriminatory criterion (sex, sexual orientation, race, national or family origin, language, religion, political or philosophical opinion). It takes place with the intent to violate the dignity of a person or to create an offensive, harmful, humiliating, degrading, and intimidating environment.

According to the Constitutional Court, the recommendation was noted to validate the rules already in action that exhort to access restorative justice of bullying and cyberbullying, instead of a disciplinarysanctioning process which was the common path in educational institutions. Restorative justice should be used in cases of bullying and cyberbullying. It enables spaces for reconciliation and restoration of the damage caused and involves victims, perpetrators, and the educational community in the process.

Considering the severe damage caused by cyberbullying, it is advisable to propose recommendations such as implementing school programs that inform potential victims of the precautions they should take to avoid virtual harassment. Furthermore, it must be emphasized that links with strange or suspicious characteristics should be avoided, unknown contacts should not be accepted, and personal data should not be published on social networks.

School life has challenges of coexistence typical of community life. One of these elements is bullying. It is a phenomenon that has significant consequences on the development of children and adolescents. It also affects their personality and the forms of adaptation the individual has in the different contexts in which he/she interacts. School is one of the scenarios of human development and implies facing different social, cultural, and family contexts. Social networks are part of this process, and, therefore, these "virtual relationships" can become common problems of coexistence.

Ensuring peaceful school coexistence is a goal of the State. It must be understood 
that it does not seek to eliminate conflicts because these are part of human nature. However, they can be dealt with without the use of violence. According to the Colombian Constitutional Court, any public policy requires three conditions: It exists; it guarantees the effective enjoyment of the right; and that the processes of decision making, elaboration, implementation, and evaluation of public policy allow for democratic participation. The second condition implies that it is impossible to speak of public policies without being clear about the actions that seek to guarantee their implementation. In this case, we cannot speak of a public policy in school coexistence without an adequate system for its assurance.

The SIUCE and the IAR constitute the National System of School Coexistence and Training for the Exercise of Human Rights -SNCE, for its initials in Spanish-, created by Law 1620 of 2013 and regulated by Act 1965 of 2013. Both tools must respond effectively to situations that affect school coexistence. Cases such as that of Sergio David Urrego Reyes, who was initially harassed by his schoolmates and systematically by officials of the educational institution on account of his sexual orientation, should be a reference that leads to a question of whether the SNCE is fulfilling its purpose. Either because it is not known by the actors involved or because it is not sensitive to the real problems that affect school coexistence, there are still situations that raise alarms.

Although the NSSC is composed of a complex network of preventive and corrective actions that, from an objective point of view, can lead to an assurance of school coexistence, the decision to implement most of these actions is in the hands of individuals. Implementing a correct system depends entirely on their correct assessment of the situations that arise in schools. On the other hand, a wrong decision or assessment can cost lives on some occasions, such as the one described in these lines.

It is also important to highlight that the NSSC cannot be merely a symbolic public policy, not accompanied by real and concrete actions. In this case, there is no doubt there is a program, but the lack of supervision and audit has made it impossible to confirm that it is working. In addition, it is even difficult to measure if it is serving its purpose of creation. Therefore, it is highly recommended that the Administration bill a new law that enables the city educational authorities to audit the implementation of NSSC and fix a dateline. Then, we could affirm that a public policy in Colombia aims to prevent and mitigate the effects of bullying and cyberbullying.

\section{ACKNOWLEDGMENT}

The researchers would like to thank all the authors and colleagues who were cited in our work. Their studies made our research possible.

\section{REFERENCES}

Abbasi, S., Naseem, A., Shamim, A., \& Qureshi, M. A. (2018, November 21-22). An empirical investigation of motives, nature and online sources of cyberbullying [Paper Presentation]. 
14th International Conference on Emerging Technologies, ICET 2018, Islamabad, Pakistan. https://doi.org/10.1109/ICET.2018.8603617

Abdel-Wahab, M. (2012). Cultural globalization and public policy: Exclusion of foreign law in the global village. In M. Freeman (Ed.), Law and sociology (pp. 76-125). Oxford University Press. https://doi.org/10.1093/acpro f:oso/9780199282548.003.0020

Abuín-Vences, N., Maestro-Espínola, L., \& CordónBenito, D. (2019). Internet, smartphones y redes sociales como factores determinantes en el incremento de casos de ciberacoso [Internet, smartphones and social media as determining tools in the rise of cyberbullying cases]. Espacios, 40(4), 23-37. http://www.revistaespacios.com/ a19v40n04/a19v40n04p23.pdf

Act 1965. (2013, September 11). Presidency of the Republic of Colombia. Official journal no. 48.853. https://www.mineducacion.gov.co/1621/ articles-328630_archivo_pdf_Decreto_1965.pdf

Alcaine, P. B., \& Sánchez, E. V. (2020). How the education community perceives cyberbullying: A comparison of students, teachers and families. Journal of New Approaches in Educational Research, 9(2), 216-230. https://doi.org/10.7821/ naer.2020.7.554

Alfaro, A. C. (2020). Acoso escolar, ciberacoso y las nuevas tecnologías de la información y la comunicación [Bullying, cyberbullying and the new information and communication technologies]. Revista Cubana De Medicina General Integral, 36(3), 1-12.

Arrieta-Lopez, M. (2019). De la democracia a la aretecracia: Origen, evolución and universalización [From democracy to the aretecracia: Origin, evolution and universalization]. Utopia y Praxis Latinoamericana, 24, 115-132. https:// produccioncientificaluz.org/index.php/utopia/ article/view/29689
Arrieta-López, M. (2020). De la paz y las repúblicas planetarias del siglo de las luces a la materialización de la paz perpetua y la ciudadanía universal [From peace and the planetary republics of the century of lights to the materialization of perpetual peace and universal citizenship]. Utopía y Praxis Latinoamericana, 25, 473-488. http://doi.org/10.5281/zenodo.4278408

Arrieta-López, M. (2018). La Aretedemocracia o Virtudemocracia: Un sistema de gobierno calificado contra las deformaciones de la democracia [Aretedemocracy or Virtuedemocracy: A system of qualified government against deformations of democracy]. Justicia, 23(34), 539-554. https://doi. org/10.17081/just.23.34.3406

Arrieta-Lopez, M., Linero-Racines, R., SanchezMontero, E., \& Carrasquilla-Diaz, L. (2019). Aspectos jurídicos y neuropsicológicos del ciberbullying en el ámbito de las TIC en Colombia [Legal and neuropsychological aspects of cyberbullying in the field of ICT in Colombia]. Opción, 35(89/2), 985-1022. https://www. produccioncientificaluz.org/index.php/opcion/ article/view/27516

Barreda, M., Feliu, L., Gutierrez, V., \& Sánchez, V. (2012). Democracia, gobernabilidad y globalización [Democracy, governance and globalization]. Universitat Oberta de Catalunya.

Bechara-Llanos, A. (2018). Investigación-acciónjurídica: Escenarios para una investigación activa y crítica en el derecho [Investigationlegal action: scenarios for an active and critical investigation in the law]. Juridicas CUC, Legal 14(1), 211-232. https://doi.org/10.17981/ juridcuc.14.1.2018.10

Carvalho, M., Branquinho, C., \& de Matos, M. G. (2021). Cyberbullying and bullying: Impact on psychological symptoms and well-being. Child Indicators Research, 14(1), 435-452. https://doi. org/10.1007/s12187-020-09756-2 
Chan, T. K. H., Cheung, C. M. K., \& Lee, Z. W. Y. (2021). Cyberbullying on social networking sites: A literature review and future research directions. Information and Management, 58(2) https://doi.org/10.1016/j.im.2020.103411

Eyuboglu, M., Eyuboglu, D., Pala, S. C., Oktar, D., Demirtas, Z., Arslantas, D., \& Unsal, A. (2021). Traditional school bullying and cyberbullying: Prevalence, the effect on mental health problems and self-harm behavior. Psychiatry Research, 297(11) 243-276. https://doi.org/10.1016/j. psychres.2021.113730

Guinot, J. (2013). Bullying o acoso escolar [Bullying or scholar harassment]. Psicología Granollers. http://www.psicoleg.info/2013/03/bullying-oacoso-escolar.html

González-Prada, M., Buelga, S., \& Ortega, J. (2015). Suicidio en adolescentes víctimas de ciberbullying: Un análisis exploratorio [Suicide in adolescent victims of reference: An exploratory analysis]. University of Valencia.

Hernández, J., Chumaceiro, A., \& Atencio, E. (2009). Calidad de servicio y recurso humano: Caso estudio tienda por departamentos [Quality of service and human resource: Case study department store]. Revista Venezolana de Gerencia, 14(47), 457-470. http:// produccioncientificaluz.org/index.php/rvg/ article/view/10544

Hinduja, S., \& Patchin, J. (2010) Bullying, cyberbullying, and suicide. Archives of Suicide Research, 14(3), 206-221. https://doi.org/10.10 $80 / 13811118.2010 .494133$

Kowalski, R. M., Giumetti, G. W., Schroeder, A. N., \& Lattanner, M. R. (2014). Bullying in the digital age: A critical review and metaanalysis of cyberbullying research among youth. Psychological Bulletin, 140(4), 1073-1137. https://doi.apa.org/doiLanding?doi=10.1037/ a0035618
Kowalski, R. M., \& Limber, S. P. (2013). Psychological, physical, and academic correlates of cyberbullying and traditional bullying. Journal of Adolescent Health, 53(1 SUPPL), S13-S20. https://doi.org/10.1016/j.jadohealth.2012.09.018

Law 1098. (2006, November 8). Congress of the Republic of Colombia. Official journal no. 46.446. http://www.secretariasenado.gov.co/ senado/basedoc/ley_1098_2006.html

Law 1620. (2013, March 15). Congress of the Republic of Colombia. Official journal no. 48.733. http://www.secretariasenado.gov.co/ senado/basedoc/ley_1620_2013.html

Li, Q. (2006). Cyberbullying in schools: A research of gender differences. School Psychology International, 27(2), 157-170. https://doi. org/10.1177/0143034306064547

Obstfeld, M. (2021). Two challenges from globalization. Journal of International Money and Finance, 110, 102301. https://oi. org/10.1016/j.jimonfin.2020.102301

Olweus, D. (1998). Conductas de acoso y amenaza entre escolares [Behaviors of harassment and threat among schoolchildren]. Ediciones Morata, S. L.

Piedrahita, I. (2011). Aproximación a las implicaciones juridicas del ciberbullying tratándose de menores de edad como sujetos activos del mismo [Approach to the legal implications of the reference in the case of minors as active subjects of itself]. CES University. http://repository.ces. edu.co/bitstream/10946/1919/2/Aproximacion_ implicaciones\%20juridicas.pdf

Political Constitution of Colombia. (1991, July 20). Constituent assembly of Colombia. Constitutional gazette no. 116. http://www. secretariasenado.gov.co/senado/basedoc/ constitucion_politica_1991.html

Ruling T-261. (1995, June 20). Constitutional Court of the Republic of Colombia (José 
Gregorio Hernández, RP). https:// www.corteconstitucional.gov.co/ relatoria/1995/T-261-95.htm

Ruling C-351. (2013, June 19). Constitutional Court of the Republic of Colombia. Corte (Jorge Pretelt, RP). https://www.corteconstitucional. gov.co/relatoria/2013/C-351-13.htm

Ruling T-365. (2014, June 11). Constitutional Court of the Republic of Colombia (Nilson Pinilla, RP). https://www.corteconstitucional.gov.co/ relatoria/2014/t-365-14.htm

Ruling T-478. (2015, August 3). Constitutional Court of the Republic of Colombia (Gloria Ortiz, RP). https://www.corteconstitucional.gov.co/ relatoria/2015/t-478-15.htm

Ruling T-713. (2010, September 8). Constitutional Court of the Republic of Colombia (María Calle, RP). https://www.corteconstitucional.gov.co/ relatoria/2010/T-713-10.htm

Ruling T-787. (2004, August 18). Constitutional Court of the Republic of Colombia (Rodrigo Escobar, RP). https:/www.corteconstitucional.gov.co/ relatoria/2004/t-787-04.htm
Roldán, E. (2013). Acoso escolar, terror en las aulas. ¿Cómo abordar el acoso escolar o bullying? [Bullying, terror in the classrooms. How to deal with bullying?]. Eess.

Secretary of Education of Bogotá. (2019). Gestión educativa [Educational management]. https:// www.educacionbogota.edu.co/portal institucional/gestion-educativa/descripcionconvivencia-escolar

Silva, A. (2008). La globalización cultural y las tecnologías de información comunicación en la cibersociedad [Cultural globalization and information communication technologies in the cybersociety]. Razón y Palabra, 64. https:// www.researchgate.net/publication/28234497 La_globalizacion_cultural_y_las_tecnologias_ de_informacion_comunicacion_en_la_ cibersociedad

Velásquez, R. (2009). Hacia una nueva definición del concepto "política pública" [Toward a new definition of the concept of "public policy"]. Desafios, (20), 149-187. https://revistas.urosario. edu.co/index.php/desafios/article/view/433/377 
